\title{
Branding Strategy Taman Herbal Bejo In Bandung City as One Way Tackling Environmental Problems In Urban Areas
}

\author{
Yanti Setianti ${ }^{1}$, Henny Sri Mulyani ${ }^{2}$, Feliza Zubair ${ }^{3}$, \\ \{yanti.setianti@unpad.ac.id ${ }^{1}$, henny.sri.mulyani@unpad.ac.id ${ }^{2}$, feliza.zubair@unpad.ac.id ${ }^{3}$ \} \\ ${ }^{1,2,3}$ Universitas Padjadjaran, Indonesia
}

\begin{abstract}
This research was conducted on "Taman Herbal Bejo" tourist attraction, which has begunp in 2014 and has appeared in several areas including Jakarta, Bandung, Yogyakarta, Semarang and Surabaya. The innovation of "Taman Herbal Bejo" is expected to be able to deliver many positive impacts including in making the environment to be more neat, beautiful and also useful. One of this research objectives is about how the branding strategy is carried out by "Taman Herbal bejo" through the mass media in attracting tourists, as well as how the strategy is done by the mass media. The tourism brand identity is a symbol of attraction for the tourists. This research is done to see the impact of branding identity establishment in mass media to tourist visit. Authors would like to see the circumstances, In terms of both the company and the stakeholders. The research method used for this study is the qualitative descriptive with case study method. The results showed that the branding identity strategy on Tribun mass media from the Bintang Toedjoe which making some approach to the stakeholders, such as the Ministry of Environment and Forestry has been done to make Bandung citizens and also people who come from anywhere to visit this new tourism identity brand, has been well executed and evaluated. Hopefully in the future, the habit of planting some of herbal/medicinal plants can be carried out by all citizens, in which every citizen will be advised to use his or her yard to be planted with some herbs, vegetables, and other plants. So it can support them economically, ecologically, socio-culturally, and so on. strategy branding identity is done to make the community in the bandung district as well as the people who are in dishes visit the new tourist identity brand that is implementated and well evaluated. Hope in the future the culture of planting medicinal plants is carried out by all citizens of the city where every citizen is advised to use his yard to plant herbs, vegetables, and others so that it can support economically, ecologically, socio-culturally and so on. Thus there will be no more idle land and vacant land, other than to make a good use and impact for both the environment as well as the surrounding residents.
\end{abstract}

Keywords: Brand,Identity, strategy, tourism, and stakeholders

\section{Introduction}

Innovative efforts in building and developing a city resulting to a consequence of increasing need for lands to accommodate the city development itself. The available potentially vacant lands are decreasing. The changing use of land function will cause a degradation to the quality of environment. Furthermore, this development will be affecting the existence of city green open space as one of city ecosystem components which will have less attention, even though the existence of the city green open space is expected to overcome environmental problems around the city. One of the innovations in supporting the green open space is "Taman Herbal Bejo" which was established since 2014 and later spreads to several other cities such as Jakarta, Bandung, Yogyakarta, Semarang, and Surabaya. This "Taman 
Herbal" (Herbal Plantation Park) innovation is expected to be able to deliver many positive impacts such as the more neat, beautiful, and also useful environment.

Environment is the blend of natural resources such as land, water, air, mineral, Flora and fauna which exist on land or in the sea and the society who will decide on how to use the physical environment. Furthermore, it can also be defined as anything which exists surround human beings who utilize their environment wisely and positively to support their life style. Therefore any information concerning the good environment in the form of knowledge or regulation must be informed or communicated to make all the life systems, from the simple to the complex, fulfilling each function to survive and to do the life-system. Nowadays, environmental damages occur in many places.[1]

Environmental Communication has two functions, the pragmatic and the constitutive. The Pragmatic concerns with giving education, giving awareness, convincing, mobilizing, and helping human kinds in overcoming the environmental problems. While The Constitutive understanding concerns with the aspects of organizing, arranging, and representing natural and environmental problems as the subject of human understanding.[2]

The problem is about how this innovation will be absorbed by the citizens. Therefore the precise and effective Communication strategy is going to be needed. The success of a communication act effectively determines more by the stipulation of Communication strategy itself. The word "strategy" itself is from a Greek word " stratēgos", which means "military general" in Athens democratic era. Strategy is an overall approach related to the implementing planned concept, and the execution of an activity in a period of time. In handling the communication problems, the planners will meet several problems, especially those in relation to the using of available Communication resource strategy in achieving their objectives. Roger (1982) gives a limitation to the Communication strategy definition as a plan which is made to change the human behaviors in the bigger scale through new ideas transfer. [3]

The Brand Manager of Bintang Toedjoe Corp. Mr. Sumarwoto said that the establishing background of Taman Herbal Bejo Jahe Merah 2019 is a form of the company's caring through the CSV ( Corporate Social Value ) of the corporation in the environmental, economic, educational, and health sectors. He said that this program will also be utilized to reintroduce the cultivation and preservation of herbal plants to public in which these acts have started to be abandoned. "Our coming is to give an education to people or public about many benefits of the herbal plants can give for our health", He said.[4]

The need of green open space in all cities will be directly proportional with the population growth each year. The availability of green open space Has become an urgent need in the cities. Green open space according to our law no. 26 year 2007 is an elongated area/path and/or a cluster, and it opens for public, a place where plants grow, whether they grow naturally or are planted intentionally.[5]

Prior researches which related to our research are as follow : the result of a research which was done by Pratiwi\&Nitibaskara\&Salampessy showed that public perception in this matter is quite high and it was shown by percentage which takes up approximately $90 \%$ to $93,34 \%$, which marked as their well-understanding toward life that their life is very depending to their cultural forestry resources. Therefore they wish that the resources can be managed sustainably. The community dependency towards their cultural forestry ecosystem is very high, especially in supporting their economic life. Having a high understanding behavior which is shown by percentage of approximately $73,33 \%$ to $93,33 \%$ means that public has a well-understanding about the conservation activities in managing their cultural forest. The village authorities need to make some regulations concerning law to identify and set the arable land for each resident around the forest area. Training programs and community 
empowerment need to be done by making collaborations with any related non-governmental organizations.[6]

Based on the result of reseach done by Sari\&Golar\&Toknok, this research revealed about the institutional form of a communal farmer group called "Palupi" ini Pakuli Village which has a legal and incorporated form. -This institutional farmer group in Pakuli Village was formed by their community and has been existed before the SCBFWM project. The Division of business development and community empowerment has done a socialization and has supervised their business activities, and has increased their business activities along with the women capacity. While The Division of Survey and Mapping has a responsibility in supervising the group activities and giving reports about the village environment existence. The Division of Socialization and Public Relation has a duty in managing relation among the community itself and also doing the socialization in the activity form and also doing some cooperation or collaboration with the outsiders for the purpose and development of their groups. The Division of Rehabilitation and Reforestation has a responsibility in reviewing the surrounding area of the village, the environment sustainability, and also in planting and nursery. [7]

Other researches on family herbal plants showed that Indonesia, in fact, has been using the herbal traditional plants since a long time ago as a medicinal substance.There are 34 collections of herbal plants which have been used by the people of Muna Tribe. From those 34, 31 of them have been able to be identified for their scientific names, but the other 3 have not. Parts of those plants used as the medicinal substance can be the whole plants or just one part of them (e.g. the roots, the stems, the leaves, the flowers, the fruit, and the seed). From all those collections, they can be used in curing at least 22 different types of diseases. People use those plants by boiling them, roasting them, or just squishing or smashing them before using.[8]

Various facts which have been shown earlier, has showed us the importance of this research on Branding Strategy Taman Herbal Bejo ini Bandung City as On Way Tackling (Overcoming) Environmental Problems in Urban Areas which is one of the innovations done by Bintang Toedjoe Corp., and that is by establishing The Taman Herbal Bejo ini several other Cities in Indonesia and Bandung City as the pilot project. It needs a strategy with benefits and contribution out of this innovation of Taman Herbal Bejo for the environment as The Green Open Space and as family herbal plants which is needed by the people and as a sustainable innovation act.

\section{Research methods}

This research needs to be done with its natural background, to able it in applying the qualitative approach with case study method. Referring to Guba and Lincoln statement in Mulyana, this research used constructivism paradigm, relativism with local or specific reality which is constructed altogether to become an ontology aspect. The epistemology aspect in the constructivism paradigm is transactional or subjective as the co-created innovation. While the methodology aspect is hermeneutic or dialectic.[9] As Moleong stated that the qualitative study is a scientific study which has a purpose to understand a phenomenon in social context naturally by putting forward a deeper communication interaction process between the researcher and the studied phenomenon.[10]

According to Mulyana, a case study is a comprehensive description and explanation on various aspects of an individual, or a group of people. In the single case study, it is possible to conduct a deeper and more specific exploration on certain cases or events out of a 
phenomenon. All data will be collected, transcripts, sorted, and then put into classifications to facilitate the analyzing data process. The data selection process concerning the relevant and credible data, doing data reduction, and highlighting the main points to make the research becoming more focus and directed. The last step is doing an interpretation of the data through the researcher personal point of view with the help of theories. [9]

\section{Results and Discussion}

Mr.Sumarwoto as The LOA and also The Public Relations Head of Bintang Toedjoe Corp. stated that 2006 is the beginning of CSV (Creating Share Value) with its branding Bejo ini the commercial side, to make it more sustainable from the manager of Taman Herbal Bejo and society. CSV has a sustainable benefits for both of the corporation and the society. So far, there are 3 ways in fulfilling the need of Red Ginger which has a high anti-oxidant agent, and they are: 1) Collaborating with the ginger farmers and has been fostering aroun 3000 plasma farmers, and also give them free training and coaching, along with the post-harvest purchasing. 2) Collaborating with The Lido BNN community up to 100 people. 3) Supporting all Taman Herbal Bejo community activities. In the 2020 agenda, they will invite The President in Delta Mas, for the purpose of the inauguration of the herbal plantation factory as one of Bejo Branding Strategies.

To perform this branding, the right and appropriate strategy is needed. Based on the result of this research, there are 5 steps of Branding Strategy which are suitable with the 5-step communication planning model which was stated by Cangara in his book "The communication strategy and planning. Middleton stated that the communication Strategy is the best combination of all communication elements from the communicators, messages, media, receivers, to the designed effects to reach the optimal Communication objectives. The strategy selection is a crucial step which needs a care handling in Communication planning because if the selected strategy is wrong or is a mistake, then the result will not be suitable with the expectation, as in term of time, assets/material, and energy. The 5-step communication planning model consists of research, plan, execute, measure, and report.[3]

The Taman Herbal Bejo Plan : The Taman Herbal Bejo has begun since 2015. At first Bintang Toedjoe Corp. wish to perform the CSR program which is not only to give a philanthropy contribution, but they also wish to create a sustainable program and has a community developing orientation. Taman Herbal Bejo is a part of The CSV (Creating Share Value) program which is more sustainable and different from the other CSR programs which mostly are incidental or uncertain. The values in which wished to be spread out of this program are: (1) The educational value in educating people about the benefits of herbal plants. (2) The economic value in educating people to do business with the red Ginger and (3) The environmental value in giving the greening effect to the environment. Bintang Toedjoe Corp. later put a plan of a Taman Herbal Bejo development program in Bandung City.

The program executors for red Ginger cultivation in the field area are mostly done by The Family Welfare Program members. The program in Bandung was carried out by giving seed and fertilizer subsidy for the Park (Taman) Mantainance and quality improvement along with the subsidy provision.

The Taman Herbal Bejo Execution: Taman Herbal Bejo Program was done gradually. In 2015 Bintang Toedjoe Corp. started to introduce The Taman Herbal Bejo ini several Cities as the pilot projects. Ini the early stage, 6 new parks were established in 3 cities: 1 park (Taman) ini Surabaya, 1 park in Medan, and 4 parks in Jakarta (one park is situated across the Bintang Toedjoe Corp. factory, another one in Ria Rio, and two other places). But 
unfortunately, through times, The Park in Medan was damaged and was even stolen by the locals and later left abandoned after it was ruined. Then the program changed into establishing the Park (Taman) for every cities. Later The Bintang Toedjoe Corp. planned to make Taman Herbal Bejo developing program other Cities such as Yogyakarta, Surabaya, Semarang, and Bandung. But the program design in these 4 cities are not the same with the program design for Jakarta, concerning to some regulations given by The Chief of The Family Welfare Program and each Mayor of each city. Herbal plants are plants which have the medicinal benefits for daily use. They are, such as Ginger, Tumeric, Curcuma, Ginseng, Garlic, etc. In developing those herbal plants in Indonesia, Bintang Toedjoe Corp. is building a factory along with the herbal Park using an International scale of Hi-Tech.[11]

The management of family herbal plants and herbal Bejo plants in Bandung has a high successful rate compares to the other executor cities of Taman Herbal Bejo Bintang Toedjoe corp. The cool weather, the fertile soil, with some suitable sunlight intensity are several out of many successful factors for planting the red Ginger in Bandung. But the success of Taman Bejo Program ini Bandung is not $100 \%$. The alacrity and enthusiasm factors of the family welfare program members as the spearheads of this Taman Herbal Bejo Program also hold a very important role. Many areas chosen for this program have failed in cultivating, growing to harvesting the red Ginger. Anthusiasm, determination, and passion for this Taman Herbal Bejo especially the red ginger also hold a very important part. Data gained in field area, the success rate of Taman Herbal Bejo Program ini Bandung is almost $70 \%$.

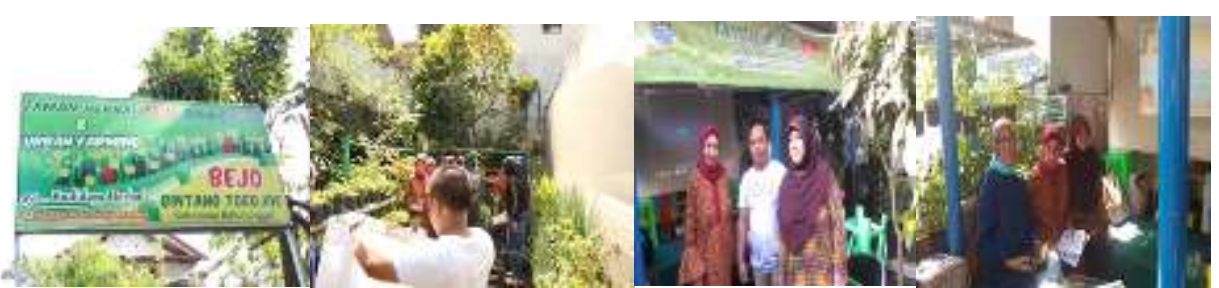

Picture 1: Taman Herbal Bejo and Saung Bejo in Batununggal sub-district, has become a relaxing place as well as a discussion place, and also as the exhibit place for the herbal product sales. [12]

Taman Herbal Bejo in Batununggal sub-district has various herbal plants around the area, herbal plants are plants which have the ability to cure many kinds of diseases that human beings may have. This Taman (park) is different from the other parks around Bandung city. While the other parks are functioned as leisure or gathering places for public.Taman Herbal Bejo ini Bandung is focusing its goal in cultivating herbal plants or medicinal plants. Since its establishment, Taman Herbal Bejo has received some achievements, and that is not a surprising thing since it's been handled very well by the Batununggal residents, which is Lead by Mr. Arik Muhammad Zakaria, and also a resident there. "It has won as the 3rd winner of Taman Herbal Bejo competition in 2016 for Bandung Area, and then became the 2nd winner in 2017 for the same competition. It has received good responses from the local residents in managing the Park and many of them ask for the seed of these plants, to be planted in their own yards/houses." Said Arik. Not only the enthusiastic residents, Arik also claimed that the local authority also pays some attention to their Taman Herbal Bejo well. [13]

In Batununggal Taman Bejo, there is also "Saung Bejo", it is a kind of shop that sales the herbal products from Bintang Toedjoe and the benefits from the sales is divided evenly to the management o the Park as well as to the management of Saung Herbal (the shop). Greening 
the environment is an effort which can be done by every citizen in Bandung area, starting from each individual in a family environment. Hopefully this act can add more to the Green Open Space as a whole. According to the concept, a green open space is an elongated area like paths, or a cluster area. The use of it is open for public, it is also a place to grow plants, whether they are planted naturally or intentionally.

Program Evaluation: By the end of each year, an evaluation program is held to see the success rate of the program itself. Therefore, during the evaluation program starting 2018, the development of Taman Herbal Bejo muat also include a cultivation training and fostering program. The execution, however, still has some problems according to the result of the evaluation program, especially due to uninformed citizens on how to cultivate the red Ginger itself. There is a problem occurs during the program in Bandung, where the seed of the red ginger was rotten when spreading out in the field due to the lack of knowledge in handling the seed. The seed which was supposedly used directly, was being kept for a long period of time, instead. Therefore $50 \%-60 \%$ of the seed is damaged or rotten. And some of the seed was also carried away by the flood when it happened. To prevent the same incident to happen, Bintang Toedjoe Corp. later then facilitates some tutors to teach the red Ginger cultivation.

Response towards Taman Herbal Bejo: So far Public seems to accept even happily accepting this program, there is no any sort of resistance. Bintang Toedjoe Corp. has given more than 3.5 billions from its budget for the 5 cities in 2017. Starting 2018, Bintang Toedjoe Corp. also has been giving Ginger seed with good standard quality for the use in Bintang Toedjoe factory. Accompanied by the tutors, in 2018 program has been done in 4 cities such as Yogyakarta, Semarang, Bogor, and Bandung. Overall, the response received from these 4 cities is good. Based on such information, Bintang Toedjoe Corp. has developed the similar programs in those 4 cities, such as material provision/counseling, seed and growing media giving, opening more WhatsApp groups for consultation or counseling, supervising, and training in 3 stages each year.

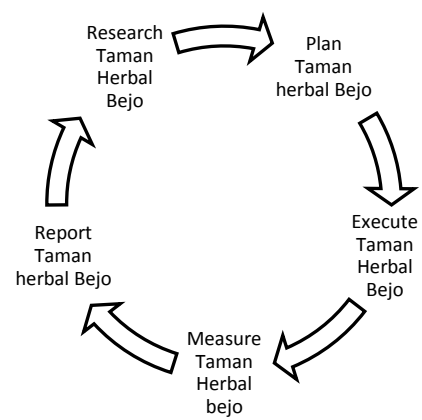

Ficture 2. The 5-step communication planning model of Taman Herbal Bejo

In the process of branding Taman Herbal Bejo along with the model given by Cangara in his book of 5-step communication strategy and planning, and they are: 1) Research which is meant to reveal the problems faced by Bintang Toedjoe Corp. in developing Taman Herbal. 2) Plan which is an act of Bintang Toedjoe Corp. after perform a diagnose and gained 
branding strategy of Bintang Toedjoe through Taman Herbal Bejo Program. 3) The execution is the establishment of Taman Herbal Bejo ini several sub-districts in Bandung. 4) Measure which is done to reveal the result of Taman Bejo Competition which is held once a year, and 5) Report which is the last act of Taman Herbal Bejo Program after finishing the activities and each year the winner of Taman Herbal Bejo Competition Will be reported or announced based on a set of criteria of the judgement.

\section{Conclusion}

Bintang Toedjoe Corp. has made a Branding Strategy through Taman Herbal Bejo which has been well-executed, starting from doing some researches although being done incomprehensibly, but still well-planning and the on-time execution act, doing the measure and evaluation, and giving reports of Taman Herbal Bejo activities by the end of each year.

\section{References}

[1] Mulyani\&yanti\&Feliza, "Communication \& Information Beyond Boundaries," in Book Chapter, vol. 53, no. 9, Bandung: Aksel, 2013, pp. 683-691.

[2] R. Cox, Environtment communication and public sphere, Second. USA: Sage Publication, 2010.

[3] Cangara, Perencanaan dan Strategi Komunikasi. Jakarta: Raja Grafindo, 2014.

[4] Portaltiga.com, "Bintang Toedjoe Akan Gelar Lomba Taman Herbal Bejo Jahe Merah Se-Jatim," 2019.

[5] P. R. Indonesia, "UNDANG-UNDANG REPUBLIK INDONESIA NOMOR 26 TAHUN 2007 TENTANG PENATAAN RUANG," in Kementrian Hukum dan Hak Aasasi Manusia Republik Indonesia, 2007, vol. 1, no. 235, p. 245.

[6] Pratiwi\&Nitibaskara\&Salampessy, "PERSEPSI DAN SIKAP MASYARAKAT TERHADAP PENGELOLAAN HUTAN ADAT ( Studi Kasus di Kasepuhan Pasir Eurih , Desa Sindanglaya ," J. Nusa Sylva, vol. 18, no. 1, pp. 31-37, 2018.

[7] Sari\&Golar\&Toknok, "KELEMBAGAAN KELOMPOK TANI HUTAN PROGRAM PENDAMPINGAN SCBFWM DISEKITAR SUB DAERAH ALIRAN SUNGAI MIU ( KASUS DESA PAKULI KECAMATAN GUMBASA KABUPATEN SIGI )," War. Rimba, vol. 1, no. 1, 2013.

[8] Jumiarni\&Komalasari, "Masyarakat Suku Muna Di Permukiman Kota Wuna Inventory of Medicinal Plants As Utilized By Muna Tribe in," Tradit. Med. J., vol. 22, no. April, pp. 45-56, 2017.

[9] D. Mulyana, Metodologi Penelitian Kualitatif. Bandung: Remaja Rosdakarya, 2018.

[10] Moleong, Metodologi Penelitian Kualitatif. Bandung: PT Remaja Rosdakarya, 2010.

[11] P. Puspita, "PT Bintang Toedjoe Siapkan Destinasi Wisata Taman Herbal Tebesar di Indonesia," 2019.

[12] Tim Peneliti, "Foto Penelitian," 2019.

[13] Destinasibandung, "Mahasiswa KKN Unpad Kunjungi Taman Bejo Sebagai Sarana Edukasi," 2019. 